\title{
DAMPAK BAURAN PEMASARAN TERHADAP KEPUTUSAN KONSUMEN DALAM MEMBELI PRODUK JASA PT. ASURANSI SINARMAS JEMBER
}

\section{IMPACT OF MARKETING MIXES ON CONSUMER DECISIONS IN BUYING SERVICES PRODUCTS PT. ASURANSI SINARMAS JEMBER}

\author{
Devita Indriani ${ }^{1}$ dan M Naely Azhad ${ }^{2}$ \\ Fakultas Ekonomi Universitas Muhammadiyah Jember ${ }^{12}$ \\ Email: naelyazhad@unmuhjember.ac.id
}

\begin{abstract}
ABSTRAK
Penelitian dengan judul Analisis Pengaruh Bauran Pemasaran (Marketing Mix) Terhadap Keputusan Konsumen Dalam Membeli Produk Jasa PT. Asuransi Sinarmas bertujuan untuk mengetahui pengaruh variabel-variabel bauran pemasaran (marketing mix) berupa produk, harga, tempat, dan promosi baik secara simultan maupun parsial terhadap keputusan konsumen dalam membeli produk jasa PT Asuransi Sinarmas dan untuk mengetahui variabel bauran pemasaran (marketing mix) berupa produk, harga, tempat, dan promosi yang dominan mempengaruhi keputusan konsumen dalam membeli produk jasa PT Asuransi Sinarmas. Data yang digunakan dalam penelitian ini berupa data primer yang diperoleh melalui penyebaran kuesioner kepada responden, yaitu nasabah PT Asuransi Sinarmas yang berjumlah 70 responden. Teknik pengambilan sampel dalam penelitian ini menggunakan teknik purposive sampling. Untuk analisis data penulis menggunakan analisis linier berganda. Berdasarkan hasil penelitian variabel marketing mix yang terdiri dari produk, harga, promosi dan tempat secara simultan dan parsial berpengaruh signifikan terhadap keputusan konsumen dalam membel produk jasa PT. Asuransi Sinarmas Jember. Variabel produk merupakan variabel dominan pengaruhnya terhadap keputusan konsumen dalam membeli produk jasa PT. Asuransi Sinarmas Jember.
\end{abstract}

Kata Kunci: Produk, Harga, Promosi, Tempat dan Keputusan Pembelian

\begin{abstract}
Thesis entitled Analisis Pengaruh Bauran Pemasaran (Marketing Mix) Terhadap Keputusan Konsumen Dalam Membeli Produk Jasa PT. Asuransi Sinarmas, aims to determine the influence of the marketing mix variable in the form of product, price, place, and promotion on both simultaneously and partially on the consumer's decision to purchase PT Asuransi Sinarmas products and services to determine the marketing mix variable in the form of product, price, place, and promotion of the dominant influence in the consumer's decision to purchase the PT Asuransi Sinarmas products and services. The data used in this study are primarily obtained through questionnaires to 70 respondents of PT Asuransi Sinarmas customers. This study uses Purposive Sampling Technique and Multiple Linear Analysis. Based on the research results of marketing mix variables consist of product, price, promotion and place simultaneously and partially has significant effect on the consumer's decision to purchase the PT. Asuransi Sinar Mas Jember products. Variable products are the most dominant influence variable on the consumer's decision to purchase the PT. Asuransi Sinarmas Jember product.
\end{abstract}

Keywords: product, price, promotion, place, and the consumer's decision 


\section{PENDAHULUAN}

Perkembangan dunia bisnis menunjukkan bahwa setiap pelaku bisnis atau perusahaan harus menghadapi persaingan yang semakin ketat, baik persaingan perusahaan yang sejenis maupun dengan perusahaan lainnya. Tujuan didirikannya suatu perusahaan salah satunya untuk mendapatkan keuntungan, baik keuntungan finansial maupun non finansial. Perusahaan harus mampu menciptakan produk yang memuaskan kebutuhan dan keinginan konsumen agar dapat mempertahankan eksistensinya.

Aspek pemasaran yang memegang peranan penting dalam mencapai tujuan perusahaan tersebut terdiri dari beberapa variabel-variabel yang tergabung dalam bauran pemasaran (marketing mix). Variabel-variabel bauran pemasaran (marketing mix) terdiri dari produk, harga, tempat dan promosi. Bauran pemasaran tersebut dipakai sebagai dasar menentukan macam produk, alternatif harga, tempat, dan promosi yang perlu dilakukan. Penilaian bauran pemasaran yang tepat memegang peranan penting dalam usaha meningkatkan volume penjualan, karena itu kesalahan pihak perusahaan dalam memadukan bauran pemasaran akan mempengaruhi tingkat keuntungan yang dicapai (Swastha dan Irawan, 1996:35). Variabel-variabel bauran pemasaran tersebut mempengaruhi perilaku konsumen dalam menentukan pilihan atau keputusan pembelian produk perusahaan, maka dari itu pemasar harus mempelajari dan memahami bagaimana konsumen berperilaku. Perilaku konsumen merupakan kegiatan-kegiatan individu yang secara langsung terlibat dalam mendapatkan dan mempergunakan barang-barang dan jasa (Swastha, 1999:9). Berdasarkan pengertian tersebut, perilaku konsumen mencakup hal-hal yang sangat luas dan sangat kompleks, yaitu keseluruhan aktivitas konsumen yang tidak hanya kegiatan fisik tetapi juga proses emosi dan mental untuk mendapatkan dan mempergunakan suatu produk sehingga kebutuhan dan keinginan konsumen dapat terpenuhi atau dengan kata lain terpenuhi atau dengan kata lain tercapai kepuasan yang optimal.

PT. Asuransi Sinarmas kembali mempertahankan Peringkat National Insurer Financial Strength (IFS) di 'AA+(idn)' dengan Outlook Positif yang dikeluarkan oleh PT. Fitch Ratings Indonesia pada 12 November 2014. Outlook Positif mencerminkan perbaikan dalam kinerja operasional PT. Asuransi Sinarmas yang berkesinambungan sementara fundamental keuangan tetap kuat. Rasio gabungan perusahaan (agregat dari rasio beban komisi dan rasio kerugian yang timbul) tetap di bawah 90\% secara konsisten selama lima tahun terakhir dan mencapai 72,2\% pada akhir Juni 2014 (2013: 80.3\%). 
Kinerja operasional yang dapat dipertahankan yang didukung oleh peningkatan permodalan perusahaan akan menjadi katalis positif untuk rating.

Program bauran pemasaran yang dikembangkan PT. Asuransi Sinarmas Jember merupakan salah satu alat pemasaran jasa yang utama untuk mencapai tujuan. Program tersebut merupakan fungsi yang memiliki kontak besar dengan lingkungan eksternal, karena memegang peranan yang sangat penting sebagai strategi dan kebijakan perusahaan untuk mewujudkan kepuasan nasabah.Kunci utama untuk memenangkan persaingan dan terjaminnya kontinuitas perusahaan adalah dengan memberikan nilai dan kepuasan nasabah melalui produk dan jasa yang berkualitas dengan harga bersaing. Kepuasan nasabah merupakan indikator kesuksesan bisnis di masa depan, karena pada hakikatnya untuk menciptakan kepuasan nasabah yang maksimal dibutuhkan waktu yang cukup lama sebelum dapat membangun dan mendapatkan reputasi atas layanan prima. Program kepuasan nasabah tidak mendatangkan keuntungan pada jangka pendek, akan tetapi hasilnya dapat dinikmati dalam jangka panjang dan dapat bertahan lama. Kepuasan nasabah mempunyai pengaruh yang besar bagi perusahaan salah satu manfaatnya yaitu dapat mendorong terciptanya loyalitas.

Berdasarkan uraian yang telah dijelaskan, penulis tertarik untuk melakukan penelitian tentang pengaruh bauran pemasaran (marketing mix) terhadap keputusan konsumen dalam membeli produk jasa PT. Asuransi Sinarmas Jember. Adapun tujuan dari penelitian ini adalah untuk mengetahui pengaruh variabel-variabel bauran pemasaran (marketing mix) berupa produk, harga, tempat, dan promosi baik secara simultan maupun parsial terhadap keputusan konsumen dalam membeli produk jasa PT Asuransi Sinarmas serta variabel yang paling dominan pengaruhnya terhadap keputusan konsumen dalam membeli produk jasa PT Asuransi Sinarmas Jember.

\section{TINJAUAN PUSTAKA}

\section{Pemasaran dan Bauran Pemasaran}

Pemasaran merupakan bagian terpenting dalam perusahaan serta merupakan ujung tombak dalam mencapai tujuan perusahaan. Salah satu tujuan dari kegiatan pemasaran untuk mengembangkan produk dan memperoleh laba dari produk yang dihasilkan. Menurut Kotler (1997:6) mengatakan bahwa, "Pemasaran adalah suatu proses manajerial yang membuat individu dan kelompok memperoleh apa yang dibutuhkan lewat penciptaan dan pertukaran timbal- balik produk dan nilai dengan orang lain”. 
Menurut William J. Stanton dalam bukunya (Basu Swasta dan Irawan, 1999:5), bahwa pemasaran adalah suatu sistem keseluruhan dari kegiatan-kegiatan usaha yang ditujukan untuk merencanakan, menentukan harga, mempromosikan dan mendistribusikan barang dan jasa yang dapat memuaskan kebutuhan baik kepada pembeli yang ada maupun pembeli potensial.

Kebijaksanaan pemasaran sebagai sebuah implementasi strategi merupakan kebijaksanaan yang dijadikan pedoman bagi manajer pemasaran untuk bertindak. Pemasaran sangat mengandalkan pada perencanaan penawaran organisasi. Dilihat dari segi kebutuhan dan keinginan pasar penggunaan penetapan harga, komunikasi serta distribusi yang efektif dapat memberikan kepuasan terhadap keinginan dan kebutuhan pembeli atau konsumen.

Kegiatan pemasaran sangat membantu perusahaan untuk mengenali kebutuhan konsumen serta mengkombinasikan dengan data pasar seperti jumlah konsumen, lokasi dan penghasilan mereka. Inti dari sistem pemasaran adalah marketing mix atau bauran pemasaran. Menurut Kotler (1997:82) menyatakan bahwa, "Bauran pemasaran adalah seperangkat alat pemasaran yang digunakan perusahaan untuk mencapai pemasarannya dalam pasar sasaran”. Elemen-elemen bauran pemasaran terdiri dari empat bagian yaitu: produk, harga, lokasi dan promosi. Elemen bauran pemasaran tersebut diuraikan sebagai berikut:

1. Produk

Produk adalah segala sesuatu yang ditawarkan kepada pasar untuk diperhatikan, dicari, digunakan atau dikonsumsi untuk memuaskan kebutuhan manusia. Berkaitan dengan produk, Kotler (1997:24) mendefinisikan produk sebagai berikut: Produk adalah segala sesuatu yang dapat ditawarkan di pasar untuk mendapatkan perhatian, dibeli, dipergunakan atau dikonsumsi dan yang dapat memuaskan keinginan dan kebutuhan konsumen.

Pemasar dalam merencanakan penawaran produk perlu memahami tingkatan produk, menurut Hurriyati (2005:51) tingkatan produk adalah sebagai berikut:

a. Produk utama atau inti, yaitu manfaat yang sebenarnya dibutuhkan dan akan dikonsumsi oleh pelanggan dari setiap produk.

b. Produk generic yaitu produk dasar yang mampu memenuhi fungsi produk yang paling dasar (rancangan produk minimal agar dapat berfungsi). 
c. Produk harapan, yaitu produk formal yang ditawarkan dengan berbagai atribut dan kondisinya secara normal diharapkan serta disepakati untuk dibeli.

d. Produk pelengkap, yaitu berbagai atribut produk yang dilengkapi atau ditambahi berbagai manfaat dan layanan, sehingga dapat memberikan tambahan kepuasan dan dapat dibedakan dengan produk pesaing.

e. Produk potensial, yaitu segala macam tambahan dan perubahan yang mungkin dikembangkan untuk suatu produk dimasa mendatang.

\section{Harga}

Harga merupakan salah satu aspek penting penting dalam kegiatan pemasaran, karena harga akan langsung mempengaruhi besarnya volume penjualan dan laba dicapai oleh perusahaan. Menurut pendapat Swasta Irawan (1990:241) menyatakan bahwa, "Harga adalah jumlah uang (ditambah beberapa produk) yang dibutuhkan untuk mendapatkan sejumlah kombinasi dari produk dan pelayanannya”. Penetapan harga dapat ditentukan melalui 5 metode (Philip Kotler, 1997:115) yaitu:

a. Penetapan harga mark up (mark up princing) adalah penetapan harga paling dasar yaitu dengan cara menambahkan atau mark up standar biaya produk.

b. Penetapan harga adalah penetapan harga produk perusahaan dengan cara menentukan harga yang akan menghasilkan tingkat pengembalian atas investasi (return on investment).

c. Penetapan harga berdasarkan nilai yang dipersepsikan yaitu penetapan harga berdasarkan persepsi pembeli mengenai nilai dan bukan pada biaya penjual.

d. Penetapan harga sesuai harga yang berlaku yaitu penetapan harga menurut keadaan, menetapkan harga mengikuti harga bersaing.

e. Penetapan harga penawaran tertutup yaitu penetapan harga berdasarkan pendapat mereka (biasanya untuk lelang).

\section{Tempat}

Pendistribusian dapat diartikan sebagai kegiatan pemasaran yang berusaha memperlancar dan mempermudah penyampaian barang atau jasa dari produsen ke konsumen, sehingga penggunaannya sesuai dengan yang diperlukan (jenis, jumlah, harga, tempat dan waktu). Dalam pelaksanaan aktivitas distribusi perusahaan juga memperhatikan penentuan lokasi perusahaan agar mudah dijangkau oleh konsumen. Penentuan lokasi tidak dapat dilakukan secara sembarangan, tetapi harus 
mempertimbangkan berbagai faktor pemilihan suatu lokasi. Adapun variabel-variabel yang mempengaruhi pemilihan suatu lokasi adalah sebagai berikut:

a. Dekat dengan pusat bisnis

b. Mudah dijangkau

c. Tempat parkirnya memadai

4. Promosi

Promosi merupakan salah satu bentuk komunikasi pemasaran yang dilakukan perusahaan kepada konsumen. Promosi dilakukan untuk menginformasikan adanya suatu produk kepada konsumen yang akan mendorong permintaan dan pada akhirnya dapat mempengaruhi konsumen untuk membeli. Pengertian promosi menurut Swasta dan Irawan (1990:349) mengatakan bahwa, "Promosi adalah arus informasi atau persuasi satu arah yang dibuat untuk mengarahkan seseorang atau organisasi kepada tindakan yang menciptakan pertukaran dalam pemasaran”. Promosi mencakup berbagai kegiatan antara lain:

1) Periklanan adalah sarana yang digunakan oleh perusahaan untuk menginformasikan segala sesuatu produk yang dihasilkan oleh perusahaan.

2) Promosi Penjualan, adalah bentuk persuasi langsung melalui penggunaan berbagai insentif yang dapat diatur untuk merangsang pembelian produk dengan segera dan meningkatkan jumlah barang yang dibeli pelanggan (Tjiptono, 2002:229).

3) Publisitas, merupakan pelengkap yang efektif bagi alat promosi yang lain, biasanya media bersedia mempublikasikan suatu berita yang dirasa cukup menarik dibaca khalayak ramai atau patut dijadikan berita.

4) Penjualan pribadi (personal selling), adalah adalah komunikasi langsung (tatap muka) antara penjual dan calon pelanggan untuk memperkenalkan suatu produk kepada calon pelanggan dan membentuk pemahaman pelanggan terhadap produk sehingga mereka akan mencoba dan membelinya.

\section{Perilaku Konsumen}

Perilaku konsumen adalah sebagai tindakan individu yang secara langsung terlibat dalam mendapatkan, mengkonsumsi dan menggunakan produk dan jasa, termasuk di dalamnya proses pengambilan keputusan yang mendahului dan mengikuti tindakan ini”. Lebih lanjut dikemukakan oleh Swastha (1999:9) menyatakan bahwa perilaku konsumen adalah kegiatan-kegiatan individu yang secara langsung terlibat dalam mendapatkan dan 
mempergunakan barang-barang dan jasa yang termasuk di dalamnya proses pengambilan keputusan pada persiapan dan penentuan kegiatan-kegiatan tersebut.

Faktor-faktor yang mempengaruhi perilaku konsumen, yaitu (Swastha, 1997:95):

1. Kebudayaan merupakan faktor penentu yang paling mendasar dari keinginan dan perilaku seseorang. Pengaruh kebudayaan akan perilaku konsumen akan selalu berubah-ubah setiap waktu sesuai dengan perkembangn jaman.

2. Kelas sosial, masyarakat Indonesia dapat dikelompokkan ke dalam tiga golongan yaitu:
a. Golongan atas
b. Golongan menengah
c. Golongan rendah

3. Kelompok referensi kecil, sering dijadikan pedoman oleh konsumen dalam bertingkah laku, oleh karena itu konsumen selalu mengawasi kelompok tersebut, baik tingkah laku fisik terdiri dari serikat buruh, lingkungan tetangga, perkumpulan agama dan lain sebagainya.

4. Keluarga, dalam keluarga masing-masing anggota memiliki selera, kebutuhan dan keinginan yang berbeda-beda.

5. Pengalaman, dapat mempengaruhi pengamatan seseorang dalam bertingkah laku.

6. Sikap kepercayaan, merupakan faktor yang ikut mempengaruhi pandangan dan perilaku pembelian konsumen.

7. Konsep diri, merupakan cara bagi seseorang untuk melihat dirinya sendiri dan pada saat yang sama ia mempunyai gambaran tentang diri orang lain.

\section{Keputusan Pembelian}

Konsumen dalam melakukan pembelian akan melalui proses tahap keputusan dalam membeli. Terutama terhadap keputusan pembelian yang kompleks, seperti pembelian barang mahal, pembelian pertama dan pembelian barang yang keterlibatannya tinggi. Tahap-tahapan dalam proses keputusan pembelian tersebut terdiri dari pengenalan masalah, pencarian informasi, evaluasi alternatif, keputusan pembelian dan perilaku setelah pembelian.

\section{METODE PENELITIAN}

Penelitian mengenai variabel-variabel bauran pemasaran yang mempengaruhi keputusan konsumen dalam membeli produk Asuransi kerugian ini merupakan jenis 
penelitian deskriptif, yaitu suatu metode penelitian yang menggambarkan mengenai situasi atau kejadian-kejadian. Metode ini mengakumulasi data dan memberikan gambaran terhadap fenomena-fenomena yang ada. Data yang dipergunakan adalah data primer. Data primer merupakan data yang diperoleh secara langsung dari pimpinan perusahaan baik yang dilakukan melalui wawancara, observasi, dan alat lain (Sudjana, 1996:87). Dalam penelitian ini data primer berupa: wawancara dan kuesioner.

Populasi adalah wilayah generalisasi yang terdiri dari obyek atau subyek yang menjadi kuantitas dan karakteristik tertentu yang ditetapkan oleh peneliti untuk dipelajari dan kemudian ditarik kesimpulannya (Sudjana, 1996:57). Populasi dalam penelitian ini adalah konsumen produk PT Asuransi Sinarmas. Sampel adalah sebagian dari populasi yang karakteristiknya hendak diselidiki dan dianggap bisa mewakili populasi, dimana jumlahnya lebih sedikit dari populasinya. Metode yang digunakan dalam pengambilan sampel adalah teknik purposive sampling, dimana dalam teknik ini pengambilan sampel berdasarkan kriteria tertentu yaitu responden yang berumur diatas 19 tahun yang pernah membeli produk pada PT Asuransi Sinarmas.

Menurut Supranto (1990:85): "Bila dalam penelitian melakukan analisis multivariat (regresi berganda), maka jumlah anggota sampel minimal adalah 10 kali dari jumlah variabel yang diteliti." Maka dalam penelitian ini seharusnya anggota sampel minimal adalah 5 (variabel dependen dan variabel independen) kali 10 adalah 50. Dalam penelitian ini menggunakan sampel 70 responden.

Dalam penelitian ini diamati variabel-variabel marketing mix yang mempengaruhi perilaku konsumen terhadap keputusan memilih produk jasa pada PT Asuransi meliputi:

a. Keputusan konsumen (Y), yang terdiri dari empat indikator yaitu :

1. Konsumen mengenali masalah keinginannya

2. Konsumen mengevaluasi berbagai produk dan memilih yang sesuai

3. Konsumen melakukan pembelian produk

4. Konsumen akan puas apabila keinginannya perilaku setelah pembelian dapat terpenuhi dan akan kembali akan melakukan pembelian

b. Produk $\left(\mathrm{X}_{1}\right)$, yang terdiri dari empat indikator :

1. Kualitas produk yang ditawarkan bagi konsumen

2. Kemasan produk

3. Keragaman jenis produk

4. Fasilitas produk yang ditawarkan kepada konsumen 
a. Harga $\left(\mathrm{X}_{2}\right)$, yang terdiri dari empat indikator :

1. Kesesuaian harga dengan kualitas produk

2. Harga dapat terjangkau oleh konsumen

3. Potongan harga yang ditawarkan mampu menarik minat pembeli

4. Penetapan tingkat harga

b. Tempat $\left(\mathrm{X}_{3}\right)$, yang terdiri dari empat indikator:

1. Lokasi yang mudah dijangkau, karena dilalui oleh rute angkutan umum

2. Lokasi strategis karena berada di tengah kota

3. Jarak lokasi dekat pusat bisnis

4. Lahan parkir yang memadai

Untuk mengetahui pengaruh nyata variabel-variabel bauran pemasaran terhadap keputusan membeli produk PT. Asuransi Sinarmas, maka dalam penelitian ini digunakan analisis regresi berganda. Uji $\mathrm{F}$ digunakan untuk mengetahui signifikan pengaruh variabel produk, harga, promosi, dan tempat secara bersama-sama terhadap keputusan konsumen membeli produk PT. Asuransi Sinarmas. Uji t yaitu digunakan untuk mengetahui pengaruh variabel bebas (variabel produk, harga, promosi, dan tempat) secara sendiri-sendiri terhadap keputusan konsumen membeli produk pada PT Asuransi Sinarmas.

\section{HASIL DAN PEMBAHASAN}

\section{Hasil Analisis Statistik Diskriptif}

Berdasarkan pada usia responden menunjukkan bahwa mayoritas responden berusia antara > 25 tahun yang berjumlah 36 responden $(51,4 \%)$. Responden yang berusia antara 21-25 tahun sebanyak 21 responden (30\%), sedangkan responden dengan prosentase terkecil adalah yang berusia antara 18-20 tahun, yaitu sebesar 18,6\% (13 responden). Berdasarkan jenis kelamin responden dapat diketahui bahwa mayoritas responden yang berjenis kelamin perempuan yaitu berjumlah 38 orang atau sekitar $54,3 \%$, tetapi jumlah ini berbeda tidak jauh dari responden berjenis kelamin laki-laki yang berjumlah 32 orang atau sekitar 45,7\%. Berdasarkan pada pekerjaan responden terlihat bahwa mayoritas responden penelitian adalah berprofesi sebagai karyawan di perusahaan-perusahaan swasta yaitu sebanyak 29 orang atau 41,4\%, kemudian responden yang berprofesi dalam bidang usaha (wiraswasta) sebanyak 15 responden $(21,4 \%)$. Responden yang berstatus sebagai pegawai negeri sipil dan pelajar atau mahasiswa 
masing-masing berjumlah 10 orang atau $14,3 \%$ dan sebagian kecil responden bekerja sebagai anggota TNI atau Polri adalah sebanyak 6 responden $(8,6 \%)$.

\section{Hasil Analisis Regresi Linier Berganda}

Analisis regresi linier berganda digunakan untuk mengetahui pengaruh variabelvariabel produk $(\mathrm{X} 1)$, harga $(\mathrm{X} 2)$, promosi $(\mathrm{X} 3)$ dan tempat $(\mathrm{X} 4)$ terhadap keputusan konsumen (Y). Berdasarkan analisis regresi linier berganda yang ditampilkan pada tabel di atas, maka dapat dihasilkan persamaan regresi sebagai berikut :

$$
Y=0,328+0,258 X_{1}+0,202 X_{2}+0,257 X_{3}+0,189 X_{4}+0,317
$$

Dari persamaan regresi linier berganda di atas dapat dilihat pengaruh dari variabel-variabel independen (produk, harga, promosi dan tempat) terhadap variabel dependen (keputusan konsumen), sedangkan makna dari persamaan regresi linier berganda di atas dapat dijelaskan sebagai berikut :

1) Konstanta persamaan regresi $\left(b_{0}\right)$ bernilai positif sebesar 0,328 berarti bahwa jika variabel-variabel produk (X1), harga (X2) dan promosi (X3) dan tempat (X4) sama dengan nol, maka keputusan konsumen adalah sebesar 0,328.

2) Koefisien regresi variabel produk $\left(b_{1}\right)$ bernilai positif sebesar 0,258 , berarti bahwa peningkatan produk sebesar 1 satuan maka akan terjadi peningkatan keputusan konsumen sebesar 0,258 satuan dengan asumsi variabel-variabel bebas lainnya konstan.

3) Koefisien regresi variabel harga $\left(b_{2}\right)$ bernilai positif sebesar 0,202 , berarti bahwa peningkatan Harga sebesar 1 satuan maka akan terjadi peningkatan keputusan konsumen sebesar 0,202 satuan dengan asumsi variabel-variabel bebas lainnya konstan.

4) Koefisien regresi variabel promosi $\left(b_{3}\right)$ bernilai positif sebesar 0,257 , berarti bahwa peningkatan promosi sebesar 1 satuan maka akan terjadi peningkatan keputusan konsumen sebesar 0,257 satuan dengan asumsi variabel-variabel bebas lainnya konstan.

5) Koefisien regresi variabel tempat $\left(b_{4}\right)$ bernilai negatif sebesar 0,189 , berarti bahwa peningkatan tempat sebesar 1 satuan maka akan terjadi peningkatan keputusan konsumen sebesar 0,189 satuan dengan asumsi variabel-variabel bebas lainnya konstan.

\section{Pengujian Koefisien Regresi Secara Simultan dengan Uji F}

Pengujian ini dimaksudkan untuk mengetahui pengaruh variabel-variabel independen (produk, harga, promosi dan tempat) terhadap variabel dependen (keputusan konsumen) secara simultan (bersama-sama). Hasil pengujian diperoleh nilai F-hitung sebesar 20,014 (p $=0,000)$ dan nilai F-tabel sebesar 2,513, maka F-hitung > F-tabel $(20,014>2,513)$, berarti 
bahwa di antara variabel-variabel independen (produk, harga, promosi dan tempat) minimal terdapat satu variabel yang berpengaruh signifikan terhadap variabel keputusan konsumen.

\section{Pengujian Koefisien Regresi Secara Parsial dengan Uji t}

Untuk mengetahui pengaruh variabel independen terhadap variabel dependen secara parsial digunakan uji t, dimana pengujian ini membandingkan antara t-hitung dengan t-tabel hasil dari pengujian terhadap masing-masing variabel produk, harga, promosi dan tempat terhadap keputusan konsumen. Hasil pengujian hipotesis untuk masing-masing variabel independen produk, harga, promosi dan tempat terhadap keputusan konsumen adalah sebagai berikut :

\section{Produk (X1)}

Berdasarkan Tabel 1 di atas diketahui nilai t-hitung variabel produk adalah sebesar 2,267 dengan nilai probabilitas sebesar 0,027, sedangkan nilai t-tabel adalah sebesar 1,997 , sehingga t-hitung > t-tabel $(2,267>1,997)$. Hal ini menunjukkan bahwa variabel produk secara parsial mempunyai pengaruh yang signifikan terhadap keputusan konsumen.

\section{Harga (X2)}

Berdasarkan Tabel 1 di atas diketahui nilai t-hitung variabel harga adalah sebesar 2,195 dengan nilai probabilitas sebesar 0,032, sedangkan nilai t-tabel adalah sebesar 1,997 , sehingga t-hitung > t-tabel $(2,195>1,997)$. Hal ini menunjukkan bahwa variabel harga secara parsial mempunyai pengaruh yang signifikan terhadap keputusan konsumen.

\section{Promosi (X3)}

Berdasarkan Tabel $1 \mathrm{di}$ atas diketahui nilai t-hitung variabel promosi adalah sebesar 3,107 dengan nilai probabilitas sebesar 0,003, sedangkan nilai t-tabel adalah sebesar 1,997, sehingga t-hitung > t-tabel $(3,107>1,997)$. Hal ini menunjukkan bahwa variabel promosi secara parsial mempunyai pengaruh yang signifikan terhadap keputusan konsumen.

\section{Tempat (X4)}

Berdasarkan Tabel $1 \mathrm{di}$ atas diketahui nilai t-hitung variabel tempat adalah sebesar 2,072 dengan nilai probabilitas sebesar 0,042, sedangkan nilai t-tabel adalah sebesar 1,997, sehingga t-hitung > t-tabel $(2,072>1,997)$. Hal ini menunjukkan bahwa variabel 
tempat secara parsial mempunyai pengaruh yang signifikan terhadap keputusan konsumen.

\section{Koefisien Determinasi $\left(\mathbf{R}^{2}\right)$}

Berdasarkan Tabel 1 di atas, diketahui bahwa koefisien determinasi $\left(\mathrm{R}^{2}\right)$ sebesar 0,552, yang berarti bahwa variabel-variabel independen (produk, harga, promosi dan tempat) berpengaruh terhadap variabel dependen (keputusan konsumen) sebesar 55,2\%, sedangkan sisanya yaitu sebesar 44,8\% dipengaruhi oleh faktor lain di luar model. Misalnya segi kebudayaan, sosial, pribadi dan psikologis yang dapat menghasilkan tanggapan dari pembeli untuk melakukan keputusan pembelian.

Tabel 2. Sumbangan Efektif Variabel Bebas

\begin{tabular}{cccc}
\hline Variabel & $\begin{array}{c}\text { Koefisien } \\
\text { Terstandarisasi }\end{array}$ & $\begin{array}{c}\text { Korelasi } \\
\text { Orde Nol }\end{array}$ & $\begin{array}{c}\text { Sumbangan } \\
\text { Efektif }\end{array}$ \\
\hline Produk $\left(\mathrm{X}_{1}\right)$ & 0,263 & 0,612 & 0,161 \\
Harga $\left(\mathrm{X}_{2}\right)$ & 0,236 & 0,583 & 0,138 \\
Promosi $\left(\mathrm{X}_{3}\right)$ & 0,275 & 0,480 & 0,132 \\
Tempat $\left(\mathrm{X}_{4}\right)$ & 0,217 & 0,558 & 0,121 \\
\hline Koefisien Determinasi $\left(\mathrm{R}^{2}\right)$ & & 0,552 \\
\hline
\end{tabular}

Adapun sumbangan efektif dari masing-masing variabel independen adalah produk sebesar 0,161 (16,1\%), harga sebesar 0,138 (13,8\%), promosi sebesar 0,132 (13,2\%) dan tempat sebesar $0,121(12,1 \%)$. Dari hasil tersebut maka dapat disimpulkan bahwa variabel paling dominan yang berpengaruh terhadap keputusan konsumen adalah variabel produk dengan sumbangan sebesar $16,1 \%$.

\section{KESIMPULAN DAN SARAN}

\section{Kesimpulan}

Variabel marketing mix yang terdiri dari produk, harga, promosi dan tempat berpengaruh signifikan terhadap keputusan konsumen dalam membeli produk jasa pada PT. Asuransi Sinarmas Jember baik secara simultan dan parsial. Secara simultan dibuktikan dari perhitungan yang diperoleh nilai F-hitung sebesar 20,014 lebih besar dari nilai F-tabel (2,513) dengan besarnya pengaruh variabel marketing mix terhadap keputusan konsumen adalah sebesar 55,2\%. Secara parsial dibuktikan dari perhitungan thitung dari semua variabel bebas adalah signifikan, adapun t-hitung masing-masing variabel marketing mix adalah sebesar 2,267 (produk), 2,195 (harga), 3,107 (promosi) dan tempat $(2,072)$ lebih besar dari t-tabel $(1,997)$. Variabel produk merupakan variabel 
dominan pengaruhnya terhadap keputusan konsumen dalam membeli produk jasa pada PT. Asuransi Sinarmas Jember. Hal ini dibuktikan dari nilai sumbangan efektif variabel produk sebesar $16,1 \%$ lebih besar dari nilai sumbangan efektif variabel lainnya, yaitu harga $(13,8 \%)$, promosi $(13,2 \%)$ dan tempat $(12,1 \%)$.

PT. Asuransi Sinarmas Jember diharapkan lebih memperhatikan variabel produk dengan indikator-indikator antara lain produk yang ditawarkan berkualitas, sangat menarik, lebih variatif dan memuaskan. Karena berdasarkan hasil penelitian melalui nilai sumbangan efektifnya menunjukkan pengaruh dari variabel produk adalah paling besar di antara variabel-variabel marketing mix lainnya dalam mempengaruhi keputusan konsumen dalam membeli produk jasa pada PT. Asuransi Sinarmas Jember. Perubahan perilaku konsumen beserta faktor-faktor yang mempengaruhinya hendaknya selalu dianalisis. Tindakan ini dimaksudkan bahwa pelaku bisnis selalu mencari informasi mengenai apa yang dibutuhkan dan diinginkan oleh konsumen dalam upaya untuk memenangkan persaingan.

\section{Saran}

1. PT. Asuransi Sinarmas Jember diharapkan lebih memperhatikan variabel produk dengan indikator-indikator antara lain produk yang ditawarkan berkualitas, sangat menarik, lebih variatif dan memuaskan. Karena berdasarkan hasil penelitian melalui nilai sumbangan efektifnya menunjukkan pengaruh dari variabel produk adalah paling besar di antara variabel-variabel marketing mix lainnya dalam mempengaruhi keputusan konsumen dalam membeli produk jasa pada PT. Asuransi Sinarmas Jember.

2. Perubahan perilaku konsumen beserta faktor-faktor yang mempengaruhinya hendaknya selalu dianalisis. Tindakan ini dimaksudkan bahwa pelaku bisnis selalu mencari informasi mengenai apa yang dibutuhkan dan diinginkan oleh konsumen dalam upaya untuk memenangkan persaingan. 


\section{DAFTAR PUSTAKA}

Alma, Buchari. 2000. Manajemen Pemasaran dan Pemasaran Jasa, Edisi Revisi. Jakarta: Alfabeta.

Arikunto, Suharsimi. 1993. Prosedur Penelitian Suatu Pendekatan Praktek. Cetakan ke10. Rineka Cipta. Jakarta.

Arikunto, Suharsimi. 2000. Prosedur Penelitian Suatu Pendekatan Praktik. Jakarta: Rineka Cipta.

Engel, James F, Blacwell, Roger D, Miniard, Paul W. 1994. Perilaku Konsumen. Alih Bahasa : F. X Budiyanto. Edisi Keenam. Binapura Aksara. Jakarta.

Ghozali, Imam. 2006. Aplikasi Analisis Multivariate Dengan program SPSS. Edisi Pertama. Semarang: Badan Penerbit Universitas Diponegoro.

Gujarati, Damodar, 1997, Ekonometrika Dasar, Penerbit Erlangga. Jakarta.

Hurriyati, Ratih. 2005. Bauran Pemasaran dan Loyalitas Konsumen. Bandung: CV. Alfa Beta.

Kerlinger, Fred. 1986. Asas-asas Penelitian Behavioral. Universitas Gajah Mada. Yogyakarta.

Kotler, Philip dan Amstrong, Gary. 1997. Dasar-dasar Pemasaran. Jilid 2. Terjemahan Hermawan, A. A dari Principles of Marketing (1987) PT. Prenhallindo. Jakarta.

Kotler, Philip dan Amstrong. 1997. Dasar-dasar Pemasaran. Jilid 1. Jakarta: Prehallindo.

Kotler, Philip. 1997. Manajemen Pemasaran, Analisis, Perencanaan, Implementasi dan Kontrol. Jilid I. Jakarta: Prenhallindo.

Mangkunagara, A. Anwar P. 1998. Perilaku Konsumen. Eresco. Bandung.

Setya Adi Santoso, Sigit. 2002. "Pengaruh Bauran Pemasaran Terhadap Keputusan Konsumen Untuk Membeli Produk Air Mineral Aqua di Kecamatan Sumbersari Kabupaten Jember". Skripsi. Fakultas Ekonomi Universitas Muhammadiyah Jember.

Singarimbun dan Effendi. 1998. Metode Penelitian Survey. LP35. Jakarta.

Stanton, William J. 1996. Prinsip Pemasaran. Edisi Ketujuh. Erlangga. Jakarta.

Sudjana, 1984. Metode Statistika. Edisi ketiga. Tarsinto. Bandung.

Sudjana, 1996. Teknik Analisis Regresi dan Korelasi. Bagi Para Peneliti. Tarsito. Bandung.

Supranto, J. 1990. Statistik Teori dan Aplikasi. Erlangga. Jakarta. 
Swasta, Basu dan Irawan. 1990. Manajemen Pemasaran Modern. Yogyakarta: Liberty.

Swasta, Basu dan Irawan. 1996. Manajemen Pemasaran. Liberty. Yogyakarta.

Swasta, Basu dan Irawan. 1999. Manajemen Pemasaran Modern. Liberty. Yogyakarta.

Swasta, Basu. 1999. Manajemen Penjualan. Liberty. Yogyakarta

Tjiptono, Fandi. 2002. Strategi Pemasaran. Edisi II. Yogyakarta: Andi Offset. 